\title{
Retrobulbar heavy liquid discovered 5 years postvitrectomy
}

\author{
David M Hille, ${ }^{1}$ Fionn Coughlan, ${ }^{1}$ Ian L McAllister, ${ }^{2}$ Kevin P Kennelly ${ }^{1}$
}

'Department of Ophthalmology, Royal Perth Hospital, Perth, Australia

'Lions Eye Institute, Nedlands, Australia

\section{Correspondence to \\ David M Hille,}

dmhille@gmail.com

Accepted 8 November 2017

\section{DESCRIPTION}

This report of a mass in the upper eyelid resulting from long-term complications of heavy liquid tamponade therapy of retinal detachment is a good example of learning from rare cases.

Retinal detachments may be repaired by scleral buckling, vitrectomy surgery or by a combination of both techniques. Retinal detachments repaired by vitrectomy are typically tamponaded by either gas or silicone oil. In certain complex cases, heavy liquid (perfluorohexyloctane/ polydimethylsiloxane) is used as a short-term tamponading agent that is subsequently replaced with gas or silicone oil. ${ }^{12}$

A 16-year-old woman presented with bilateral retinal detachments secondary to giant tears. The patient had no relevant ocular history and denied trauma. The left eye had a macula-sparing detachment and the right eye had a macula-off retinal detachment. Both retinas were reattached sequentially with a combination of scleral buckling and vitrectomy with heavy liquid tamponade. The heavy liquid was removed from each eye 7 days following insertion and replaced with $25 \%$ sulfur hexafluoride (SF6) gas.

Five years following the left vitrectomy, the patient presented complaining of a mobile mass beneath the lateral aspect of the right upper eyelid. The left eye was asymptomatic. Consistent with her visual acuity following the retinal detachment surgeries, her corrected visual acuity

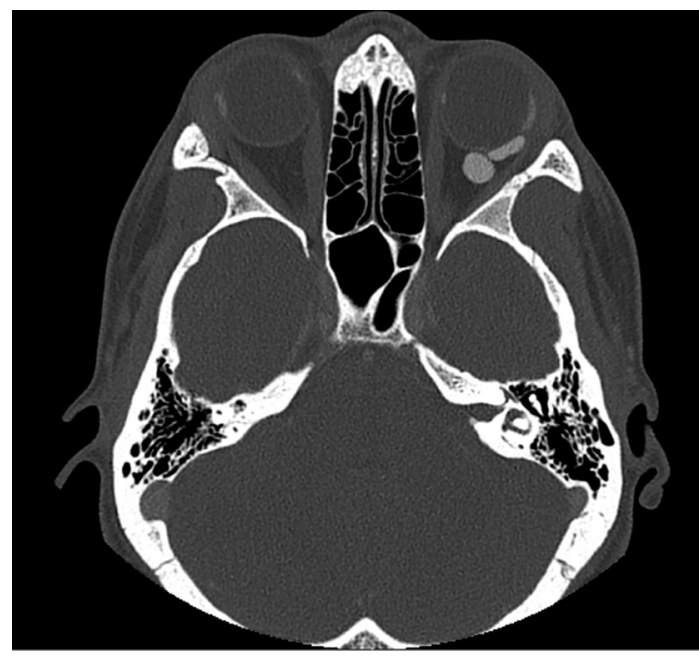

Figure 1 Axial CT scan through the orbits demonstrates hyperdense abnormalities in the left intraconal retrobulbar space.

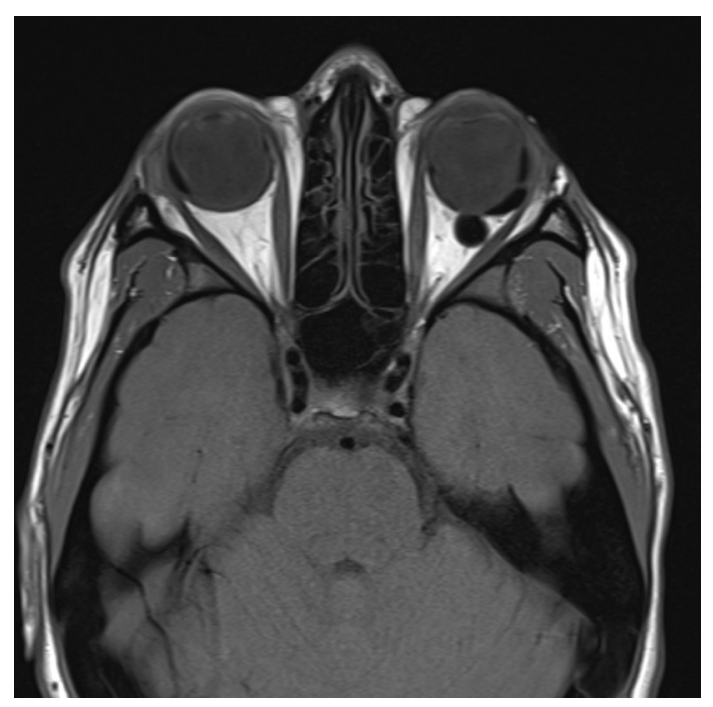

Figure 2 Axial T1 MRI scan through the orbits illustrates migrated heavy liquid in the left intraconal retrobulbar space.

was counting fingers in the right eye and 6/9 in the left eye.

A CT scan (figure 1) did not identify a lesion accounting for the mass palpated on the right upper eyelid. However, multiple hyperdense abnormalities were identified in the left intraconal retrobulbar space. A subsequent MRI (figure 2) was thought to be consistent with the presence of heavy liquid within the left intraconal retrobulbar space. The heavy liquid had apparently leaked from the vitreous cavity through unsutured 25 -gauge sclerostomy ports 5 years previously and migrated to the retrobulbar space. Interestingly, there was no consequent inflammatory reaction, orbital signs or symptoms. Asymmetrical lacrimal gland enlargement was also noted on MRI, with the right greater than the left.

Surgical removal of the retrobulbar heavy liquid was not performed as the patient was asymptomatic and was reliant on the vision in

Learning points

- A short-term heavy liquid tamponade used during vitrectomy surgery 5 years previously was incidentally found to have migrated to the retrobulbar space.

- Asymptomatic heavy liquid migration via sclerostomy ports is a rare event. 
her left eye. Asymptomatic retrobulbar heavy liquid migration via sclerostomy wounds is a rare event.

Contributors DMH is the corresponding author and was involved in all elements of case report. FC was responsible for image selection and editing. ILM was responsible for editing. KPK was involved in the editing and supervision.

Competing interests None declared.

Patient consent Obtained.

Provenance and peer review Not commissioned; externally peer reviewed. (c) BMJ Publishing Group Ltd (unless otherwise stated in the text of the article) 2017. All rights reserved. No commercial use is permitted unless otherwise expressly granted.

\section{REFERENCES}

1 Russo A, Morescalchi F, Donati S, et al. Heavy and standard silicone oil: intraocular inflammation. Int Ophthalmol 2017.doi: 10.1007/s10792-017-0489-3. [Epub ahead of print 13 Mar 2017].

2 Romano MR, Stappler T, Marticorena J, et al. Primary vitrectomy with Densiron-68 for rhegmatogenous retinal detachment. Graefes Arch Clin Exp Ophthalmol 2008;246:1541-6

Copyright 2017 BMJ Publishing Group. All rights reserved. For permission to reuse any of this content visit http://group.bmj.com/group/rights-licensing/permissions.

BMJ Case Report Fellows may re-use this article for personal use and teaching without any further permission.

Become a Fellow of BMJ Case Reports today and you can:

- Submit as many cases as you like

Enjoy fast sympathetic peer review and rapid publication of accepted articles

- Access all the published articles

Re-use any of the published material for personal use and teaching without further permission

For information on Institutional Fellowships contact consortiasales@bmjgroup.com

Visit casereports.bmj.com for more articles like this and to become a Fellow 